\title{
Factors Determining Profitability Of Islamic Bank Empisire Study In Indonesia's Sharia Banking
}

\author{
T. Muhammad Farizky \\ Department of Accounting, Univesity Of North Sumatra, Indonesia
}

\begin{tabular}{|c|c|}
\hline ARTICLE INFO & ABSTRACT \\
\hline Article history: & \multirow{4}{*}{$\begin{array}{l}\text { This research was conducted to examine the effect of variable Capital } \\
\text { Adequacy Ratio (CAR), Non-Performing Financing (NPF), Operating } \\
\text { Expenses Operating Income (BOPO), and Financing to Deposit Ratio } \\
\text { (FDR) of Profitability (ROA). Profitability is used to measure the } \\
\text { effectiveness of management based on results generated from the } \\
\text { loan repayment and investment. The ratio is important for the bank's } \\
\text { profitability is Return On Assets (ROA). Financial ratios that affect the } \\
\text { ROA is the CAR, NPF, BOPO, and FDR. The sampling technique } \\
\text { used was purposive sampling with the criteria of Islamic commercial } \\
\text { bank serving the financial statements of the period December } 2006- \\
\text { September } 2010 \text {. The analysis technique used is the classical } \\
\text { assumption of the analysis, multiple regression analysis and } \\
\text { hypothesis test with a level of significance of } 5 \% \text {. The results of the } \\
\text { research simultaneously (test F) states that the CAR, NPF, BOPO, } \\
\text { and FDR jointly affect the profitability (ROA) of banks. While the } \\
\text { results show that the correlation coefficient between profitability } \\
\text { (ROA) of banks with } 4 \text { independent variables of } 73.9 \% \text {. And the result } \\
\text { of research partially (t) states that the variable CAR and FDR did not } \\
\text { have a significant positive effect on profitability (ROA) of banks. And } \\
\text { variable BOPO NPF and significant negative effect on profitability } \\
\text { (ROA) of banks. }\end{array}$} \\
\hline $\begin{array}{r}\text { Received Sep 10, } 2021 \\
\text { Revised Oct 14, } 2021 \\
\text { Accepted Nov 30, } 2021\end{array}$ & \\
\hline Keywords: & \\
\hline $\begin{array}{r}\text { Capital Adequacy Ratio (CAR); } \\
\text { Non Performing Finance (NPF); } \\
\text { Financing To Deposit Ratio } \\
(\text { FDR); } \\
\text { Return On Assets (ROA). }\end{array}$ & \\
\hline
\end{tabular}

This is an open access article under the CC BY-NC license.

\section{Corresponding Author:}

T. Muhammad Farizky,

Department of Accounting,

University Of North Sumatra, Indonesia,

Jl. Dr. Mansur No. 9 Padang Bulan, Kec. Medan Baru, Kota Medan 20222.

Email:muhammadfarizky@gmail.com

\section{INTRODUCTION}

In the period 2007-2008, BOPO experienced a fairly large increase of 5.21 percent, while ROA decreased by 0.65 percent. In the period 2008-2009, both BOPO and ROA increased by 2.64 percent and 006 percent, respectively. Meanwhile, in the 2009-2010 period, BOPO decreased by 3.85 percent and ROA increased by 0.19 percent. This phenomenon indicates that there has been an inconsistency of the relationship between BOPO and ROA and therefore further research is necessary.

the magnitude of the FDR indicator in Islamic banking in the 2006-2007 period, FDR increased by 0.86 percent, and ROA increased by 0.27 percent. In the 2007-2008 period, FDR increased by 3.89 percent, while ROA decreased by 0.65 percent. FDR experienced a sharp decline in the period 2008-2009, namely 13.95 percent, while ROA experienced a slight increase of 0.06 percent. In the 2009-2010 period, FDR decreased by 0.03 percent and ROA increased by 0.19 percent. This 
phenomenon indicates that there has been an inconsistency of the relationship between FDR and ROA and therefore further research is necessary.

Several researchers have conducted research on financial ratios and bank profitability in Indonesia. Based on the results of previous studies, it can be concluded that financial ratios that affect bank profitability (ROA) include CAR, NPF, BOPO, and FDR (Farhan, 2011; Ikhwanisita, 2011; Dody, 2011).

CAR in the study conducted by Farhan (2011) showed a positive and significant relationship to bank profitability, while research conducted by Ikhwanisita (2011) showed a positive and insignificant relationship to profitability. Contrary to the three studies, CAR in Dody's research (2011) shows a negative relationship to profitability. Given the research gap from this study, it is necessary to conduct further research on the relationship of CAR to profitability (ROA).

NPF in the research conducted by Farhan (2011) has a negative and significant effect on profitability (ROA). However, in a study conducted by Ikhwanisita (2011), NPL showed a negative and insignificant relationship to profitability $(\mathrm{ROA})$. On the other hand, research conducted by Dody (2011) shows a positive relationship from NPF to profitability (ROA). Given the research gap from this research, it is necessary to conduct further research on the relationship between NPF and profitability $(\mathrm{ROA})$.

BOPO in research conducted by Farhan (2011) and Ikhwanisita (2011) showed a negative and significant relationship to profitability (ROA).

FDR in research conducted by lkhwanisita (2011) showed a positive and significant relationship to profitability (ROA). Contrary to these two studies, in a study conducted by Dody (2011), there was a negative relationship between FDR and profitability (ROA). Given the research gap from this study, it is necessary to conduct further research on the relationship between FDR and profitability (ROA).

This study aims to examine the factors that affect the profitability of Islamic commercial banks in Indonesia during 2006-2010. The variables used include CAR, NPF, BOPO, and FDR. Profitability is measured by ROA to determine the performance of assets owned by Islamic commercial banks in obtaining profits.

\section{RESEARCH METHOD}

Types of research this is a hypothesis testing research (Hypothesis testing). Hypothesis testing according to Indriantoro and Bambang Supomo (1999: 89) is "research that aims to test hypotheses and generally is research that explains phenomena in the form of relationships between variables". This study is intended to determine how much the independent variables contribute to the dependent variable and the direction of the relationship.

\subsection{Data Analysis Method}

The model used to test the hypothesis in this study is a multiple regression analysis model (Multiple Regression Analysis) and its processing uses the SPSS 17.0 tool. Regression analysis was used to test the ability of the financial ratio variable in determining earnings changes. After that, the $t$ statistic test and $F$ statistical test were carried out to determine whether each independent variable had a partial or simultaneous effect on the dependent variable.

\section{a. Classical Assumption Test}

a. Data Normality Test. The data normality test aims to test whether in a regression model, the dependent variable (ROA), the independent variable (CAR, NPF, BOPO, and FDR) in Islamic banking, or both have a normal distribution or not. According to Sugiyono (2006: 70), "a data that forms a normal distribution if the amount above and below the average is the same, as well as the standard deviation".

b. Heteroscedasticity Test. Heteroscedasticity test aims to test the occurrence of differences in residual variance from one observation period to another. According to Ghozali (2005: 111), "heteroscedasticity test aims to test whether in the regression model there is an inequality of variance from one observation residual to another observation".

c. Autocorrelation Test. According to Erlina (2008: 107), "the autocorrelation test aims to see whether in a linear regression model there is a correlation between the nuisance error in period $t$ and the error in period -1 ". In a good regression model, there is no autocorrelation. 
To detect the problem of autocorrelation, it can be done by using the Durbin Watson (DW) test.

d. Multicollinearity Test. Multicollinearity is a situation where there is a correlation of independent variables between one another. In this case, we call this independent variable not orthogonal (Erlina, 2008: 105). Multicollinearity testing aims to determine whether there is multicollinearity between independent variables. In a good regression model there is no correlation between independent variables. Detection is done by looking at the value of VIF (Variable Inflation Factor) and tolerance value. Multicollinearity occurs if VIF $<10$ and tolerance value $>0.10$.

\section{RESULTS AND DISCUSSIONS}

\subsection{Research Data Analysis A. Descriptive Analysis}

Descriptive analysis of the data taken for this study is from 2006 to 2010 as many as 15 observational data. Variable descriptions in descriptive statistics used in this study include the minimum, maximum, mean and standard deviation of the dependent variable, namely profitability (ROA) and four independent variables, namely CAR (Capital Adequacy Ratio), NPF (Non Performing Financing), BOPO (Operating Expenses, Operating Income), FDR (Financing to Deposit Ratio).

Descriptive statistics are concerned with collecting and ranking data. Descriptive statistics describe the character of the sample used in this study. The distribution of descriptive statistics for each variable is shown in Table 4.1 below:

Table 1. Descriptive Statistics Descriptive Statistics

\begin{tabular}{cccc}
\hline & mean & Std. Deviation & $\mathrm{N}$ \\
\hline ROA & 2.1347 & 1.20746 & 15 \\
CAR & 11.9507 & 1.54344 & 15 \\
NPF & 3.8747 & 1.81387 & 15 \\
BOPO & 82.1400 & 6.92183 & 15 \\
FDR & 88.3600 & 7.84091 & 15 \\
\hline
\end{tabular}

Table 1 shows that the average of each can be seen that during the observation period, it can be concluded that:

a. The dependent variable is profitability $(\mathrm{ROA})$ which is measured by comparing profit before tax to total assets. ROA has the lowest value with a mean value of 2.1347 and a standard deviation of 1.20746 .

b. The independent variable CAR (Capital Adequacy Ratio) which reflects capital adequacy is measured by comparing own capital to risk-weighted assets. The mean value is 11.9507 and the standard deviation is 1.54344 .

c. The independent variable NPF (Non-Performing Financing) which reflects financing risk is measured by comparing non-performing financing to total financing. The mean value is 3.8747 and the standard deviation is 1.81387 .

d. The independent variable BOPO (Operational Expense Operating Income) which reflects efficiency is measured by comparing the total operating expenses to the total operating income. The total turnover has an average value of 82,1400 and a standard deviation of 6,92183.

e. The independent variable FDR (Financing to Deposit Ratio) which reflects the bank's ability to repay withdrawals made by depositors is measured by comparing the financing provided to the total third party funds. The mean value is 88.3600 and the standard deviation is 7.84091 .

\subsection{Classic Assumption Test}

\section{a. Data Normality Test}

The data normality test aims to test whether in a data regression model, dependent variable $(R O A)$, independent variable (CAR, NPF, BOPO, FDR) in Islamic banking, or both have a normal distribution or not. Normality is generally detected by looking at the spread of data (dots) on the diagonal axis of the graph or by looking at the histogram of the residuals. 


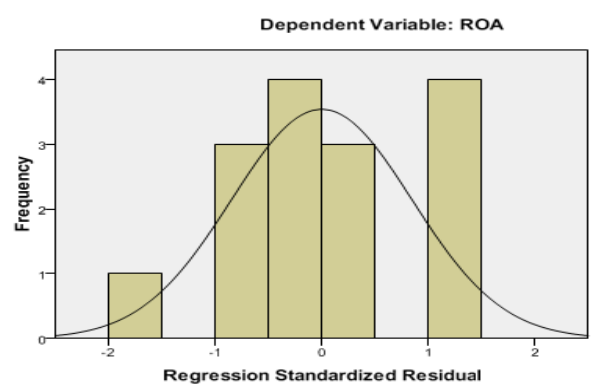

Figure 1. Histogram Normality Test

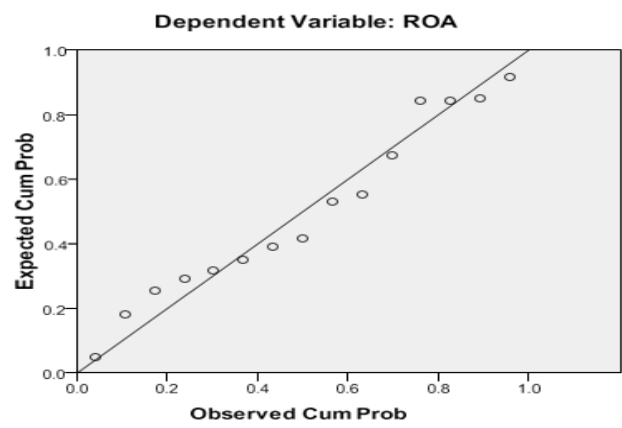

Figure 2. P-Plot Graph Normality Test

Graph analysis can be used with two tools, namely histogram graph and PP Plot graph. Good data is data that has a normal distribution pattern. In the histogram graph, the data that follows or approaches the normal distribution is the data distribution with a bell shape. In the PP Plot graph, a data is said to be normally distributed if the data points are not skewed to the left or right, but spread around the diagonal line.

By looking at the histogram graphic display in Figure 4.1 above, we can see that the graphic image is bell-shaped and not skewed to the left and right, indicating that the data is normally distributed. In the PP Plot graph in Figure 4.2 above, it can be seen that the dots spread along the diagonal line. Both graphs show that the regression model does not violate the assumption of normality.

Testing the normality of the data by just looking at the graph can be misleading if you don't look carefully, so we need to test the normality of the data using statistics to make it more convincing.

\section{b. Heteroscedasticity Test}

The heteroscedasticity test aims to test whether in the regression model there is an inequality of variance from the residual of one observation to another observation (Ghozali, 2005: 111). A good regression model is that there is no heteroscedasticity. How to detect the presence or absence of heteroscedasticity symptoms is to look at the scatterplot graph generated from data processing using the SPSS program. The basis for making the decision is as follows:

a. If there is a certain pattern, such as the dots that form a certain regular pattern, it indicates that heteroscedasticity has occurred.

b. If there is no clear pattern, and the points spread below the numbers 0 and $y$, then there is no heteroscedasticity. 
This test is carried out by observing a certain pattern on the scatterplot graph, where if there are points that spread above and below the number 0 on the $y$-axis and do not form a pattern, there is no heteroscedasticity.

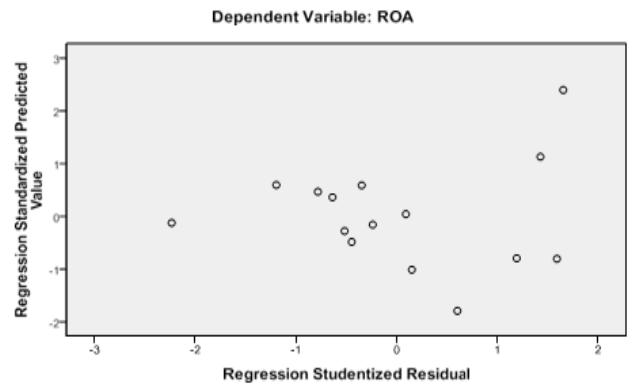

Figure 3. Heteroscedasticity Test (Scatterplot)

In Figure 3 of the scatterplot graph above, it can be seen that the points spread randomly and do not form a certain clear pattern and are spread both above and below zero on the $y$-axis. This means that there is no heteroscedasticity in the regression model so that the regression model is feasible to use to see the effect of the independent variable on the dependent variable.

\section{c. Autocorrelation Test}

The autocorrelation test aims to analyze whether in the linear regression model there is a correlation between the nuisance error in period $t$ and the $t 1$ error or before (Erlina, 2008: 106). A good regression model is one that is free from autocorrelation. To detect the problem of autocorrelation can be done by using the Durbin Watson test. Guidelines for detecting the presence or absence of autocorrelation are as follows:

1) If the DW value lies between the upper limit (dU) and (4-dU), then the autocorrelation coefficient is equal to zero, meaning that there is no autocorrelation.

2) If the DW value is lower than the lower limit (dL), then the autocorrelation coefficient of more than zero means that there is a positive autocorrelation.

3) If the DW value is more than (4-dL), then the autocorrelation coefficient is less than zero, which means that there is a negative autocorrelation.

4) If the DW value lies between the upper limit (dU) and the lower limit (dL) or DW lies between (4-dU) and (dL), the results cannot be concluded.

\begin{tabular}{cccccc}
\multicolumn{7}{c}{ Table 2. Model Autocorrelation Test Results Summaryb } \\
\hline Model & $\mathrm{R}$ & $\mathrm{R}$ Square & $\begin{array}{c}\text { Adjusted R } \\
\text { Square }\end{array}$ & $\begin{array}{c}\text { Std. Error of the } \\
\text { Estimate }\end{array}$ & Durbin-Watson \\
\hline 1 & $.902 \mathrm{a}$ & .814 & .739 & .61689 & 2,057 \\
\hline Predictors: (Constant), FDR, CAR, BOPO, NPF & &
\end{tabular}

Dependent Variable: ROA

Table 2 shows the DW statistic value of 2,057. dUtable value $=1.8719$. So, we can find the value (4-dU) that is $4-1.8719=2.1281$. From these results, it can be concluded that there is no autocorrelation because DW lies between the upper limit (dU) and (4-dU), 2.068 lies between 1.8719 and 2.1281. Thus, the regression model is free from autocorrelation problems.

\section{d. Multicollinearity Test}

Multicollinearity is a situation where independent variables are correlated with one another. In this case, we call this independent variable not orthogonal (Erlina, 2007). Orthogonal independent variables are independent variables that have a correlation value between each other equal to zero.

The test aims to determine whether there is multicollinearity between independent variables. A good regression model should not have a correlation between independent variables. ).

Detection is done by looking at the VIF (Variable Inflation Factor) value and the tolerance value. Multicollinearity occurs when the VIF value is $<10$ and the tolerance value is $>0.10$. 
Table 3. Multicollinearity Test Results

\begin{tabular}{cccc}
\hline & Model & \multicolumn{2}{c}{ Collinearity Statistics } \\
& Tolerance & VIF \\
\hline 1 & (Constant) & & \\
CAR & .543 & 1.842 \\
NPF & .744 & 1.345 \\
BOPO & .933 & 1.072 \\
& FDR & .607 & 1,647 \\
\hline
\end{tabular}

Dependent Variable: ROA

Based on table 3 above, it can be seen that none of the independent variables has a VIF value of more than 10 and none has a tolerance value less than 0.1 . So it can be concluded that this research is free from multicollinearity. From the results of this test, it can be concluded that all the independent variables used in this study passed the multicollinearity symptom test.

\subsection{Hypothesis Testing}

\section{a. Coefficient of Determination Test (R2)}

The coefficient of determination shows how much the independent variable explains the dependent variable. In this case, adjusted R2 is used to determine how much influence the CAR, NPF, BOPO, and FDR variables have on profitability (ROA). "Adjusted R2 is considered better than $\mathrm{R} 2$ because the value of adjusted R2 can increase or decrease if one independent variable is added to the model" (Ghozali, 2005).

Therefore, in this study, adjusted ${ }^{2}$ ranges between zero and one. If the adjusted . value ${ }^{2}$ The closer to one, the better the model's ability to explain the independent variables and vice versa.

\begin{tabular}{|c|c|c|c|c|}
\hline Model & $R$ & R Square & Adjusted R Square & $\begin{array}{c}\text { Std. Error of the } \\
\text { Estimate }\end{array}$ \\
\hline 1 & $.902 a$ & .814 & .739 & .61689 \\
\hline
\end{tabular}

The amount of adjusted R2 based on the results of statistical analysis obtained is 0.739 . Thus the magnitude of the effect of CAR, NPF, BOPO and FDR given to profitability (ROA) is $73.9 \%$. While the remaining $26.1 \%$ is influenced by other factors not examined in this study.

\section{b. Partial Test (t Test)}

This test aims to determine the relationship between the independent variable and the dependent variable partially (individually). The decision-making criteria are:

1) The hypothesis is accepted if tcount $>$ ttable on sig-prob<a $(0.05)$

2) The hypothesis is rejected if tcount $<$ ttable on sig-prob $>\alpha(0.05)$

If the probability (significance) is greater than $(>0.05)$, then the independent variables individually have no effect on profitability (ROA). If the probability (significance) is smaller than $(<0.05)$, then the independent variables individually affect profitability $(R O A)$. The results of this partial test can be seen in table 4.6 as follows:

\begin{tabular}{ccccc}
\multicolumn{7}{c}{ Table 5. Partial Test Results (t Test) } \\
Coefficientsa & \\
\hline Model & Unstandardized & Standardized & T & Sig. \\
& Coefficients & Coefficients & & \\
\hline 1 B & Std. Error & Beta & .062
\end{tabular}




\begin{tabular}{|c|c|c|c|c|c|}
\hline \multirow[t]{2}{*}{ Model } & \multicolumn{2}{|c|}{$\begin{array}{l}\text { Unstandardized } \\
\text { Coefficients }\end{array}$} & \multirow{2}{*}{$\begin{array}{c}\text { Standardized } \\
\text { Coefficients } \\
\text { Beta }\end{array}$} & \multirow[t]{2}{*}{$\mathrm{T}$} & \multirow[t]{2}{*}{ Sig. } \\
\hline & $B$ & Std. Error & & & \\
\hline CAR & .0 .83 & .145 & .106 & .572 & .580 \\
\hline NPF & -.336 & .105 & -.505 & $-3,188$ & .010 \\
\hline BOPO & -.114 & .025 & -.655 & -4.633 & .001 \\
\hline FDR & .032 & .027 & .208 & 1.189 & .262 \\
\hline
\end{tabular}

Dependent Variable: ROA

\section{c. Simultaneous Test (F Test)}

This test aims to test the effect of the independent variables on the dependent variable together. The decision-making criteria are:

1) The hypothesis is accepted if Fcount $>$ Ftable on sig-prob $<\alpha(0.05)$

2) The hypothesis is rejected if Fcount $<$ Ftable on sig-prob $>\alpha(0.05)$

If the probability (significance) is greater than $(>0.05)$, then the independent variables together have no effect on the profitability variable (ROA). If the probability (significance) is smaller than $(<0.05)$, then the independent variables jointly affect the profitability variable $(R O A)$. The results of this simultaneous test can be seen in table 4.7 as follows:

Table 6. Simultaneous Test Results (F Test) ANOVAb

\begin{tabular}{ccccccc}
\hline & Model & $\begin{array}{c}\text { Sum of } \\
\text { Squares }\end{array}$ & df & Mean Square & F & Sig. \\
\hline 1 & Regression & 16,606 & 4 & 4.151 & 10,909 & $.001 \mathrm{a}$ \\
Residual & 3.806 & 10 & .381 & & \\
Total & 20,412 & 14 & & & \\
\multicolumn{2}{l}{$\begin{array}{l}\text { Predictors: (Constant), FDR, CAR, BOPO, NPF } \\
\text { Dependent Variable: ROA }\end{array}$}
\end{tabular}

In table 6 above, it can be seen that the value of Fcount $>$ Ftable $(10,909>3.36)$, while the significance value is $0.0001(<0.05)$. This shows that the variables CAR, NPF, BOPO, and FDR are simultaneously proven to affect the profitability (ROA) of Islamic banks.

\section{CONCLUSION}

The CAR variable has a positive but not significant effect so that $\mathrm{H} 1$ which states that $\mathrm{CAR}$ has a positive and significant effect on the profitability $(R O A)$ of Islamic banks cannot be accepted. The NPF variable has a negative and significant effect so that $\mathrm{H}_{2}$ which states that the NPF has a negative and significant effect on the profitability (ROA) of Islamic banks is acceptable. The ROA variable has a negative and significant effect so that $\mathrm{H} 3$ which states that $\mathrm{BOPO}$ has a negative and significant effect on the profitability (ROA) of Islamic banks is acceptable. The FDR variable has a positive but not significant effect so that $\mathrm{H} 4$ which states that FDR has a positive and significant effect on the profitability $(\mathrm{ROA})$ of Islamic banks cannot be accepted.

The results of simultaneous hypothesis testing (F test) show that Fcount (10.909) is greater than Ftable (3.36) with a significance value of 0.001 so $\mathrm{H} 5$ which states that CAR, NPF, BOPO, and FDR together (simultaneously) affect profitability (ROA) Islamic banks are acceptable.

The result of the coefficient of determination test shows that the adjusted R2 value is 0.739 , which means that the ability of the independent variables (CAR, NPF, BOPO, and FDR) in explaining the dependent variable of profitability proxied by ROA is $73.9 \%$. While the remaining $26.1 \%$ is explained by other variables not examined in this study.

\section{REFERENCES}

Agistiara, Yusti, 2011. Analisis Faktor-Faktor yang Mempengaruhi Profitabilitas Perbankan Go Publik (Studi Kasus Bank Go Publik Periode Tahun 2005- 2009),Skripsi, Universitas Diponegoro : Semarang.

Dendawijaya, Lukman, 2005. Manajemen Perbankan, Edisi Kedua, Cetakan Pertama,Ghalia Indonesia, Bogor. 
Dody, Yoga Prasetyo Santoro, 2011. Analisis Pengaruh Beberapa Rasio Keuangan Terhadap Kinerja Profitabilitas Bank Umum Syariah di Indonesia Periode 2006-2009. Skripsi, UPN : Jatim.

Erlina, 2008. Metodologi Penelitian Bisnis: Untuk Akuntansi dan Manajemen, Edisi Pertama, USU Press, Medan.

Ghozali, Imam, 2005. Aplikasi Analisis Multivariate dengan Program SPSS, Edisi Ketiga, Badan Penerbit Universitas Diponegoro, Semarang.

Ikatan Akuntan Indonesia, 2002. Kerangka Dasar Penyusunan dan Penyajian Laporan Keuangan Bank Syariah, Salemba Empat, Jakarta.

Ikhwanisita, 2011. Pengaruh Rasio Keuangan Terhadap Tingkat Profitabilitas Bank Syariah Mandiri, Skripsi, Universitas Sumatera Utara : Medan.

Muhammad, 2005. Manajemen Dana Bank Syariah, Edisi Pertama, Cetakan Kedua,Ekonisia, Yogyakarta.

Rahim, Rida dan Yuma Irpa. 2008. "Analisa Efisiensi Operasional terhadap Profitabilitas pada Bank Umum Syariah dan Unit Syariah (Studi Kasus BSM dan BNI Syariah)". Jurnal Bisnis \& Manajemen, Vol 4, No 3, 2008.

Rivai, Veithzal dan Arviyan Arifin, 2010. Islamic Banking: Sebuah Teori, Konsep, dan Aplikasi, Bumi Aksara, Jakarta.

S. Munawir, 2002. Akuntansi Keuangan dan Manajemen, Edisi Revisi, BPFE, Yogyakarta.

Syafi'i Antonio, Muhammad, 2001. Bank Syariah: Dari teori ke Praktik, Gema Insani, Jakarta. 